\title{
In vitro assessment of anti-tumorigenic mechanisms and efficacy of NanoALA, a nanoformulation of aminolevulic acid designed for photodynamic therapy of cancer
}

\author{
Laise Rodrigues de Andrade ${ }^{\mathrm{a}}$, Fernando Lucas Primo ${ }^{\mathrm{b}}$, Jaqueline Rodrigues da Silva ${ }^{\mathrm{a}}$, \\ Antonio Claudio Tedesco ${ }^{c}$, Zulmira Guerrero Marques Lacava ${ }^{\mathrm{a}, *}$ \\ a University of Brasília, Institute of Biological Sciences, Center of Nanoscience and Nanobiotechnology, 70910-900, Brasilia, DF, Brazil \\ b São Paulo State University (UNESP), School of Pharmaceutical Sciences, 14801-903, Araraquara, SP, Brazil \\ ${ }^{\mathrm{c}}$ Department of Chemistry, Center of Nanotechnology and Tissue Engineering - Photobiology and Photomedicine Research Group, Faculty of Philosophy, Sciences and \\ Letters of Ribeirão Preto, University of São Paulo, 14010-100, Ribeirão Preto, Brazil
}

\section{A R T I C L E I N F O}

\section{Keywords:}

Aminolevulic-acid (ALA)

Photodynamic therapy (PDT)

Nanocarriers

Poly(lactide-co-glycolide) (PLGA)

Mammary carcinoma

\begin{abstract}
A B S T R A C T
Background: The development of nanocarriers is an important approach to increase the bioavailability of hydrophilic drugs in target cells. In this work, we evaluated the anti-tumorigenic mechanisms and efficacy of NanoALA, a novel nanoformulation of aminolevulic acid (ALA) based on poly(lactide-co-glycolide) (PLGA) nanocapsules designed for anticancer photodynamic therapy (PDT).

Methods: For this purpose, physicochemical characterization, prodrug incorporation kinetics, biocompatibility and photocytotoxicity tests, analysis of the cell death type and mitochondrial function, measurement of the intracellular reactive oxygen species production and DNA fragmentation were performed in murine mammary carcinoma (4T1) cells.

Results: NanoALA formulation, stable over a period of 90 days following synthesis, presented hydrodynamic diameter of $220 \pm 8.7 \mathrm{~nm}$, zeta potential of $-30.6 \mathrm{mV}$ and low value of polydispersity index $(0.28)$. The biological assays indicated that the nanostructured product promotes greater ALA uptake by 4T1 cells and consequently more cytotoxicity in the PDT process. For the first time in the scientific literature, there is a therapeutic efficacy report of approximately $80 \%$, after only $1 \mathrm{~h}$ of incubation with $100 \mu \mathrm{g} \mathrm{mL} \mathrm{prodrug}^{-1}$ (0.6 mM ALA equivalent). The mitochondria are probably the initial target of treatment, culminating in energy metabolism disorders and cell death by apoptosis.

Conclusions: NanoALA emerges as a promising strategy for anticancer PDT. Besides being effective against a highly aggressive tumor cell line, the treatment may be economically advantageous because it allows a reduction in the dose and frequency of application compared to free ALA.
\end{abstract}

\section{Introduction}

Aminolevulinic acid (ALA) is commonly used in photodynamic therapy (PDT) and detection (PDD) as a precursor of protoporphyrin IX (PpIX), a potent fluorescent photosensitizer. ALA is the naturally occurring first intermediate in the heme synthesis pathway, and its exogenous administration results in overproduction and preferential accumulation of PpIX in cells undergoing high metabolic turnover, providing therapeutic selectivity for dysplastic and neoplastic cells [1-7]. Upon irradiation at specific wavelength, the PpIX in triplet state reacts with molecular oxygen or other biomolecules in surrounding areas, producing reactive oxygen species (ROS), which can cause irreversible oxidative damage and trigger apoptotic and necrotic cell death [8-11].

An important advantage of PpIX relative to other photosensitizers is its fast clearance of the body - it lasts no longer than $48 \mathrm{~h}$. Subsequently, it induces low cytotoxicity in the absence of irradiation [12-14]. However, some clinical drawbacks come from ALA, the precursor prodrug of PpIX. Due to its zwitterionic and hydrophilic nature, ALA is unstable in physiological environments and presents limitations in its transport across skin or cell membranes, thus restricting the effectiveness of ALA-mediated PDT in the treatment of preneoplastic or

\footnotetext{
* Corresponding author.

E-mail addresses: laisedeandrade@hotmail.com (L.R. de Andrade), flprimo@fcfar.unesp.br (F.L. Primo), sol.jaque@gmail.com (J.R. da Silva), atedesco@usp.br (A.C. Tedesco), zulmira@unb.br (Z.G.M. Lacava).
} 
superficial diseases $[2,15,16]$. To overcome these drawbacks, different tools and strategies for improving the pharmacokinetic profile were proposed, such as application of ferrochelatase inhibitors [17], use of skin permeability enhancers [18], iontophoresis technique [19] or the use of more lipophilic ALA ester derivatives [20].

A relatively new and exciting concept for targeted and effective PDT, especially in the oncology field, is the incorporation of ALA into nanodelivery systems. In theory, these systems offer advantages over other approaches, because besides bypassing lipophilic barriers they can protect labile molecules from degradation and promote selective delivery to the target sites, avoiding possible toxic effects on healthy cells $[5,11,21]$. For instance, poly(lactide-co-glycolide) (PLGA) is one of the most studied synthetic polymers for the development of delivery systems due to its excellent biocompatibility, biodegradability, and approval for human use by the US FDA [22-24].

Although about twenty ALA nanocarriers have been designed in the last two decades [3,5,7,12-14,21,25-37], to the best of our knowledge, only two reports are found about the use of PLGA-based nanoparticles for ALA delivery. In one of them, ALA-loaded amorphous PLGA nanoparticles were effectively internalized by squamous cell carcinoma, and its photocytotoxicity was more efficient than that presented by free ALA [38]. However, a long exposure period ( $24 \mathrm{~h}$ ) was necessary to achieve a more pronounced therapeutic effect. Furthermore, this sample presented some physicochemical characteristics that are undesirable for medical purposes, such as high polydispersity index (PdI 0.62) and low loading capacity (LC $0.62 \% \pm 0.27 \%$ ), which could lead to multiscattering phenomena and particle aggregation. In the other report, conducted by our group [2], ALA-loaded PLGA nanocapsules (NanoALA) showed high stability and better properties than ALA derivative methyl aminolevulinate (MAL) for photodetection and treatment of field cancerization associated with actinic keratosis and skin photodamage, using only $2 \mathrm{~h}$ of occlusion.

Even with these positive results, the study of the effects and mechanism of action of ALA as a nanoproduct is of great importance before recommending NanoALA-PDT for broad clinical use, including safety and regulation issues. The necessity for deeper knowledge of NanoALA encouraged us to investigate the biological action, the therapeutic efficacy/efficiency and the anti-tumorigenic mechanisms of NanoALAPDT in a new preclinical experimental model. Although PDT is usually focused on skin cancer, the investigation of PDT on another type of cancer represents an expansion for its applications. Considering that a human cell line develops only in immunosuppressed mice and that there is evidence that the immune system plays a key role in response to PDT $[39,40]$, murine mammary carcinoma (4T1) cells were chosen as a therapeutic target, especially due to the high carcinogenic and invasive ability of this cell line, capable of inducing tumors analogous to stage IV human breast cancer [41]. Considering also that breast cancer is the most frequent cancer in women and that each year there are 458,000 deaths related to this cancer for lack of early diagnosis and effective treatment [42], this work may contribute to the understanding of a new safe and noninvasive treatment option, while expanding and directing future studies related to the use of nanotechnology strategies in the field of oncology.

\section{Materials and methods}

\subsection{The preparation of NanoALA}

NanoALA is an oil-in-water $(\mathrm{o} / \mathrm{w})$ polymeric nanoemulsion prepared by a spontaneous emulsification process following the protocol described elsewhere [2]. In brief, na organic phase containing poly (lactide-co-glycolide) (PLGA), egg-phosphatidylcholine lipids (50:50 w/ w polymer:lipids) and ALA (Dye Pharmaceuticals, São José dos Campos, São Paulo, Brazil) in a $20 \%$ final concentration was prepared at $55{ }^{\circ} \mathrm{C}$. This organic phase was added into the aqueous phase containing the anionic surfactant, poloxamer 188 (Sigma Aldrich, St Louis,
MO, USA) under controlled magnetic stirring. Lastly, the organic solvents were removed by evaporation under reduced pressure at $60{ }^{\circ} \mathrm{C}$ for a period of $6 \mathrm{~h}$.

\subsection{Characterization}

The average size, polydispersity index, and zeta potential of the systems were investigated by dynamic light scattering (DLS) and electrophoretic measurement (Malvern Instruments ${ }^{\circ}$ Nano ZS ZEN3600, UK). The analyses were performed with a He-Ne laser operating at $633 \mathrm{~nm}$, scattering angle of $173^{\circ}$, and temperature of $25.0 \pm 0.1^{\circ} \mathrm{C}$. For stability analysis, the formulations were stored at $4{ }^{\circ} \mathrm{C}$ and characterized by DLS for 90 days following synthesis.

\subsection{Cell culture}

4T1 mouse mammary tumor cell line (ATCC - CRL-2539 ${ }^{\mathrm{TM}}$ ) was cultured in Dulbecco's Modified Eagle Medium (DMEM, Gibco ${ }^{\circ}$ Life Technologies, Ltd., USA) supplemented with $10 \%$ (v/v) fetal bovine serum (Gibco ${ }^{\circ}$ Invitrogen $^{\mathrm{TM}}$, USA) and $100 \mathrm{IU}_{\mathrm{mL}}{ }^{-1}$ penicillin and $100 \mu \mathrm{g} \mathrm{mL}^{-1}$ streptomycin (Sigma-Aldrich). Cell cultures were routinely maintained in a humidified atmosphere containing $5 \% \mathrm{CO}_{2}$ at $37^{\circ} \mathrm{C}$.

\subsection{Uptake Profile of NanoALA in 4T1Cells}

$4 \mathrm{~T} 1$ cells $\left(5 \times 10^{4}\right.$ cells/well) were seeded in 24 -well plates and cultured for $24 \mathrm{~h}$. After being washed twice with phosphate buffered saline (PBS), cells were incubated, under light protection, with $200 \mu \mathrm{L}$ serum-free medium (SFM) containing $6.25 \mu \mathrm{g} \mathrm{mL}^{-1}$ and $200 \mu \mathrm{g} \mathrm{mL}$ NanoALA. SFM was used to avoid the ATP-binding cassette transportermediated PpIX efflux from the cell [43]; the absence of serum during treatment did not cause cell death or morphological abnormalities. However, after treatment, the cells were incubated in complete medium for $24 \mathrm{~h}$ before the tests were performed. Each hour for a period of $10 \mathrm{~h}$ and at $24 \mathrm{~h}$, the protoporphyrin IX (PpIX) fluorescence was determined using IVIS LUMINA ${ }^{\circ}$ imaging system (XRIII model, PerkinElmer, USA) in excitation and emission conditions: $420-620 \lambda_{\mathrm{ex}^{-}} \lambda_{\mathrm{em}}$. Data were corrected for autofluorescence background by cells not exposed to the PpIX precursors. All experiments were performed under the same conditions with free ALA solutions for comparison purposes.

\subsection{Comparison of ALA- and NanoALA-mediated photocytotoxicity on 4T1Cells}

4T1 cells were seeded in 96-well plates at a density of $1 \times 10^{4}$ cells/ well and cultured for $24 \mathrm{~h}$. Attached cells were washed twice with PBS solution and incubated with $200 \mu \mathrm{L}$ SFM containing NanoALA in concentrations ranging from $6.25 \mu \mathrm{g} \mathrm{m}^{-1}$ to $200 \mu \mathrm{g} \mathrm{mL} \mathrm{m}^{-1}$ for $0.5 \mathrm{~h}, 1 \mathrm{~h}$, $6 \mathrm{~h}$ or $24 \mathrm{~h}$. Dark toxicity was determined by removing the treatment solutions, followed by PBS washing and culture medium reestablishment for $24 \mathrm{~h}$. To perform PDT treatment, cells were irradiated in PBS by a $630 \mathrm{~nm}$ wavelength Light Emitting Diode (LED) at a power density of $24.9 \mathrm{~mW} / \mathrm{cm}^{2}$ and fluency of $22.44 \mathrm{~J} / \mathrm{cm}^{2}$. Following irradiation, cells were incubated in complete medium for another $24 \mathrm{~h}$. The potential cytotoxic effect was determined by (4,5-dimethylthiazol-2-yl)2,5-diphenyltetrazolium bromide (MTT) assay. MTT solution ( $0.5 \mathrm{mg} \mathrm{mL}^{-1}, 150 \mu \mathrm{L} /$ well) was added to the wells, and the cells were incubated for $2 \mathrm{~h}$ at $37^{\circ} \mathrm{C}$ in a $\mathrm{CO}_{2}$ incubator. Dimethyl sulfoxide (DMSO, $200 \mu \mathrm{L} /$ well) was added to dissolve the formazan crystals produced after discarding the supernatant. The absorbance values were measured in a spectrophotometer with a microplate reader (Molecular Devices SpectraMax M2 ${ }^{\circ}$, USA) at $595 \mathrm{~nm}$. No baseline correction was applied at log wavelength. Unloaded PLGA nanocapsules were tested previously and showed no toxicity [2,44,45], as expected [22-24]. 


\subsection{Effects of NanoALA-PDT on $4 T 1$ cell morphology}

As the MTT assay does not discriminate between cytostatic and cytotoxic activities, and nor does it differentiate the viable cells from cells in the early death process, the effect of the NanoALA- mediated PDT on 4T1 cells was investigated by phase contrast microscopy (Invitrogen EVOS FL Auto Cell Imaging System, Thermo Fisher Scientific, USA). First, the $4 \mathrm{~T} 1$ cells $\left(1 \times 10^{5}\right.$ cell/well $)$ grown in 6well-plate were incubated with $50 \mu \mathrm{g} \mathrm{mL}{ }^{-1}$ NanoALA for $1 \mathrm{~h}$. After $24 \mathrm{~h}$ of PDT (as described above), the morphological changes were examined and recorded at $200 \times$ total magnification.

\subsection{Assessment of anti-tumorigenic mechanisms of NanoALA}

NanoALA-induced cell death profile, mitochondrial membrane potential, ROS production and DNA fragmentation analyses were performed by flow cytometry. The ideal concentration for these analyses should generate two cell populations (live and dead), preferably equidistributed. For practical convenience, the shortest incubation time in which the NanoALA-PDT was able to reduce about $50 \%$ of cell viability was chosen. Briefly, at $24 \mathrm{~h}$ post-treatment, cells were harvested by trypsinization (0.25\% trypsin-EDTA; Sigma). Cell pellets were washed with $1 \mathrm{~mL}$ of ice-cold PBS and re-suspended in an appropriate buffer for incubation with specific markers. The samples were immediately analyzed by flow cytometry (FACSVerse, BD, USA) equipped with FlowJo vX 0.7 software. A total of 10,000 events per sample were analyzed. The forward scatter (FSC) and side scatter (SSC) of particles were simultaneously measured and cell debris was excluded.

\subsubsection{Apoptotic cells staining by annexin-V/propidium iodide}

To explore the mechanism underlying the reduction of 4T1 cell viability, the modes of cell death (apoptosis or necrosis) induced by NanoALA-PDT were determined by the AnnexinV-FITC/PI staining method, according to the manufacturer's instructions (BD, USA/Probes - Thermo Fisher, USA). Cell pellets were re-suspended in $400 \mu \mathrm{L}$ binding buffer [10 mM HEPES/NaOH (pH 7.4), $140 \mathrm{mM} \mathrm{NaCl}, 2.5 \mathrm{mM}$ $\mathrm{CaCl}_{2}$ ] and incubated with $5 \mu \mathrm{L}$ of Annexin-V/FITC solution for $15 \mathrm{~min}$ at room temperature in the dark. After that, the cells were incubated for an additional $5 \mathrm{~min}$ with $10 \mu \mathrm{L}$ propidium iodide (PI; $20 \mu \mathrm{g} \mathrm{mL}^{-1}$ ).

\subsubsection{Analysis of mitochondrial membrane potential $\left(\Delta y_{m}\right)$}

The mitochondrial function was monitored using rhodamine 123 , a cationic lipophilic fluorochrome that can accumulate in active mitochondria. The fluorescence intensity is proportional to the mitochondrial membrane potential $\left(\Delta \psi_{\mathrm{m}}\right)$. Mitochondrial leakage often results in the opening of membrane permeability transition pores and dissipation of the $\Delta \psi_{\mathrm{m}}$ [46], which promotes the efflux of rhodamine from mitochondria. To perform the analysis, the cells re-suspended in $1 \mathrm{~mL}$ PBS were incubated with $1 \mu \mathrm{L}$ of Rhodamine 123 solution ( $5 \mathrm{mg} \mathrm{mL}^{-1}$; Probes - Thermo Fisher, USA) for $15 \mathrm{~min}$ at room temperature in the dark. They were then washed twice with PBS and immediately analyzed.

\subsubsection{Detection of intracellular reactive oxygen species (ROS)}

Production of a significant amount of intracellular ROS is an important indicator of PDT efficiency [26]. The effect of treatment with NanoALA-PDT on the intracellular ROS level was determined by the cell-permeable CellROX Green reagent, which exhibits a strong fluorescent signal upon oxidation in the nucleus and cytoplasm of living cells. The cell suspension was incubated with $2 \mu \mathrm{L}$ of CellROX Green ${ }^{\circ}$ solution $\left(250 \mu \mathrm{M}\right.$; Molecular Probes $\left.{ }^{\circ}\right)$ for $40 \mathrm{~min}$ at $37^{\circ} \mathrm{C}$, protected from light. During the final $5 \mathrm{~min}$ of staining, $10 \mu \mathrm{L}$ propidium iodide (PI, $20 \mu \mathrm{g} \mathrm{mL}^{-1}$ ) was added. Cells treated with $20 \mu \mathrm{M}$ hydrogen peroxide $\left(\mathrm{H}_{2} \mathrm{O}_{2}\right)$ for $30 \mathrm{~min}$ were used as positive control.
Table 1

Particle size analyses for Nano-ALA formulations from dynamic light scattering technique (DLS).

\begin{tabular}{llll}
\hline & Size, $\mathrm{nm}$ & PdI & Zeta, mV \\
\hline Nano unloaded & $180 \pm 2.8$ & 0.23 & -28.5 \\
Nano-ALA & $220 \pm 8.7$ & 0.28 & -30.6 \\
\hline
\end{tabular}

"Statistical analyses from triplicate of different batches for each formulation $(n=3)$.

\subsubsection{DNA fragmentation}

Cells were fixed in $70 \%$ ethanol at $-20{ }^{\circ} \mathrm{C}$ for $24 \mathrm{~h}$. After centrifugation $\left(5 \mathrm{~min}, 10^{\circ} \mathrm{C}, 2000 \mathrm{rpm}\right.$ ), the supernatant was removed and the cells were incubated with $200 \mu \mathrm{L}$ of lysis buffer containing PI and RNase $(0.1 \%$ sodium citrate, $0.1 \%$ TritonX- $100,20 \mu \mathrm{g} / \mathrm{mL}$ propidium iodide, $250 \mu \mathrm{g} \mathrm{mL}^{-1}$ RNase) for $30 \mathrm{~min}$ at room temperature.

\subsection{Statistical analysis}

Data were expressed as mean \pm SEM. Differences among groups were tested by two-way ANOVA. Comparisons between the groups were evaluated using Tukey's multiple comparisons test. A value of $\mathrm{P}<0.05$ was considered significant.

\section{Results}

\subsection{Particle size, zeta potential and physical-chemical stability}

Table 1 shows the sample NanoALA physical-chemical characteristics obtained by DLS and electrophoretic measurement. As a result of ALA nanoencapsulation, an increase in the average hydrodynamic diameter (from $180 \pm 2.8 \mathrm{~nm}$ to $220 \pm 8.7 \mathrm{~nm}$ ) and a reduction in the zeta potential (from $-28.5 \mathrm{mV}$ to $-30.6 \mathrm{mV}$ ) were observed when compared to unloaded nanocapsules (Nano). The low value of polydispersity index (0.28) denotes the monodisperse system. Over a period of 90 days following synthesis, the NanoALA formulation remained stable in terms of hydrodynamic size and polydispersity index (PdI) (Fig. 1).

\subsection{PpIX fluorescence measurements}

The influence of prodrug concentration and exposure time on the 4T1 cell uptake rate was evaluated by the fluorescence intensity of PpIX production (Fig. 2). At the lowest concentration $\left(6.25 \mu \mathrm{gL}^{-1}\right)$, there was no considerable PpIX production by cells incubated in the dark with ALA or NanoALA, over all the period analyzed. The highest concentration $\left(200 \mu \mathrm{g} \mathrm{mL}^{-1}\right)$ of ALA led to a subtle amount of PpIX only after $24 \mathrm{~h}$. At this time, the fluorescence intensity was around four times higher in cells incubated with NanoALA. It is important to note that the NanoALA uptake did not progressively increase. The PpIX production increased by approximately $50 \%$ in $1 \mathrm{~h}$ and $30 \%$ in $6 \mathrm{~h}$, which was enough to generate a different cytotoxic effect.

\subsection{NanoALA biocompatibility}

To test the effects of NanoALA on 4T1 cells, the MTT assay was first performed under dark conditions. In agreement with the PpIX fluorescence measurements, the results indicate that the NanoALA biocompatibility is dependent on both concentration and exposure time (Fig. 3, DARK). Incubation for 0.5, 1 and $6 \mathrm{~h}$ with both samples (ALA and NanoALA) had no effects on the cell viability, and the reduction was about $10 \%$ for all concentrations tested. However, after $24 \mathrm{~h}$ of incubation with high concentrations of NanoALA there was a significant loss of cell viability. NanoALA at concentrations of 50, 100 and $200 \mu \mathrm{g} \mathrm{mL}^{-1}$ reduced, respectively, about $15 \%, 40 \%$ and $63 \%$ of cell viability compared to control group (cells without treatment). ALA 


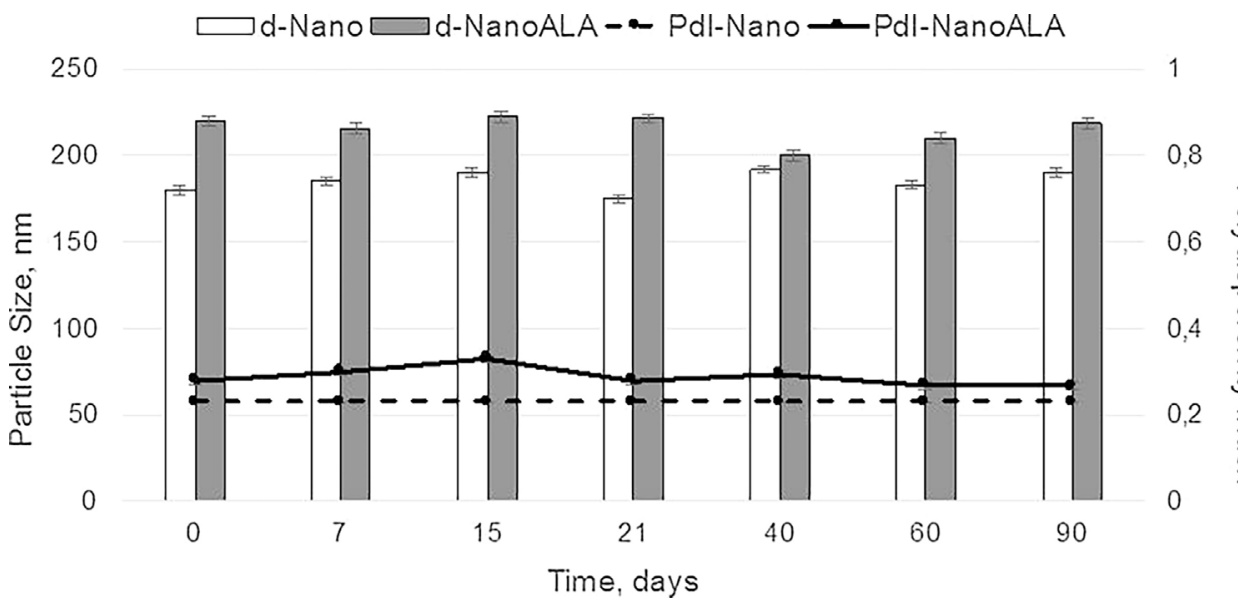

Fig. 1. Physical-chemical stability of Nano and NanoALA formulations (unloaded and loaded with aminolevulinic acid, respectively) obtained from DLS analyses until 90 days after synthesis $(n=3)$. alone did not affect the cell viability in the same conditions.

\subsection{NanoALA-PDT efficiency and cell morphology}

The PDT treatment using concentrations higher than $6.25 \mu \mathrm{gL}^{-1}$ NanoALA was photocytotoxic when the incubation times were 1,6 and $24 \mathrm{~h}$, while the ALA solutions were photocytotoxic only after $24 \mathrm{~h}$ of incubation (Fig. 3, PDT). After $1 \mathrm{~h}$ of NanoALA incubation, the cell viability was reduced from $11 \%\left(12.5 \mu \mathrm{g} \mathrm{mL}^{-1}\right.$ NanoALA) to $78 \%$ ( $200 \mu \mathrm{g} \mathrm{mL} \mathrm{m}^{-1}$ NanoALA), and the living cells showed morphological abnormalities, such as cell shrinkage, membrane damage, and innumerable cytoplasmic vacuoles (Fig. 4). The NanoALA-mediated photocytotoxicity after $6 \mathrm{~h}$ of incubation was significantly lower than in $1 \mathrm{~h}$ for the same concentrations, except in the concentration of $25 \mu \mathrm{g} \mathrm{mL} \mathrm{m}^{-1}$, which did not present a significant difference. For example, the inhibitory rate decreased from $78 \%$ at $1 \mathrm{~h}$ to $59 \%$ at $6 \mathrm{~h}$ using $200 \mu \mathrm{gL}^{-1}$ NanoALA. After $24 \mathrm{~h}$ of incubation the cytotoxic effect of NanoALA was enhanced dramatically. At $12.5 \mathrm{ug} \mathrm{mL}^{-1} \mathrm{Na}-$ noALA the viability was reduced to $46 \%$, reaching $90 \%$ reduction in the higher concentrations $\left(\geq 50 \mu \mathrm{g} \mathrm{mL}^{-1}\right)$. ALA-mediated photocytotoxicity was significantly lower than the NanoALA. About $56 \%$ to $76 \%$ of viability was reduced in ALA concentrations $\geq 50 \mu \mathrm{gL}^{-1}$.
Together, these results evidence the enhanced efficacy of NanoALAmediated PDT compared to the free ALA-PDT, since a much longer incubation time was required for ALA to achieve a similar effect to $1 \mathrm{~h}$ of incubation with NanoALA.

\subsection{Analysis of the cell death profile}

Fig. 5 indicates the percentage of intact $4 \mathrm{~T} 1$ cells (unmarked), cells in early apoptosis with intact membranes (AnnexinV-FITC ${ }^{+}$), late apoptosis/necrosis $\left(\mathrm{PI}^{+} /\right.$AnnexinV-FITC ${ }^{+}$) and necrotic cells $\left(\mathrm{PI}^{+}\right)$ after different treatments. In the absence of irradiation, 4T1 cells incubated with $50 \mu \mathrm{gL}^{-1}$ ALA or NanoALA for $1 \mathrm{~h}$ did not show any significant increase in the percentage of apoptotic and/or necrotic cells compared to the control. It is important to note that irradiation alone does not sensitize cells or induce cell death, excluding a possible thermal effect of light, observed by MTT as well. After NanoALA-PDT, the percentages of early apoptotic cells ( $8 \%$ ) and late apoptotic/necrotic cells (16\%) were significantly higher than in the control group. NanoALA-PDT probably induces plasma membrane alterations that culminate in a loss of integrity at subsequent times, as was observed in microscopy images (Fig. 4).
A

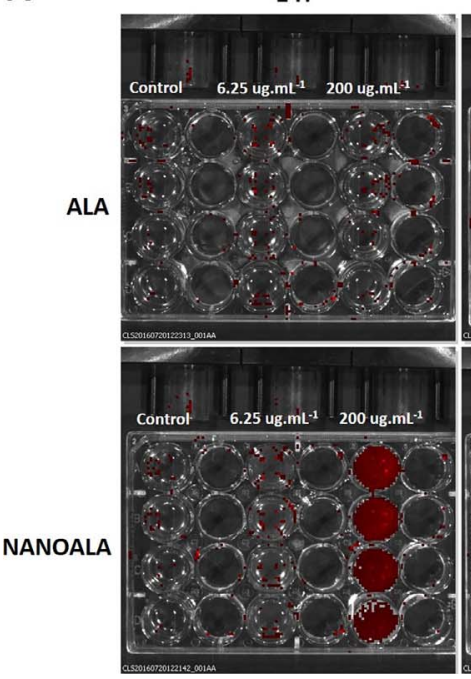

$24 \mathrm{H}$

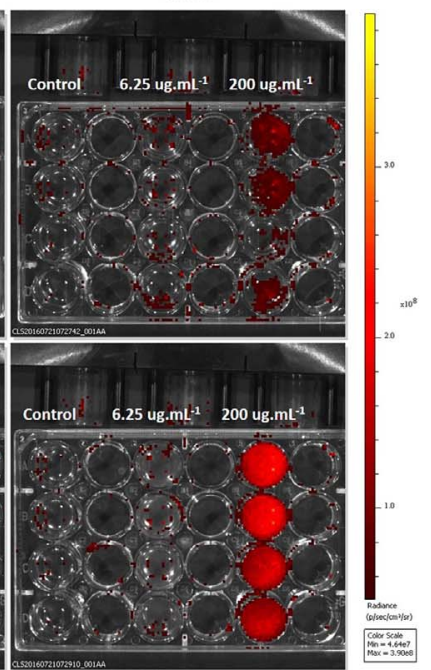

B

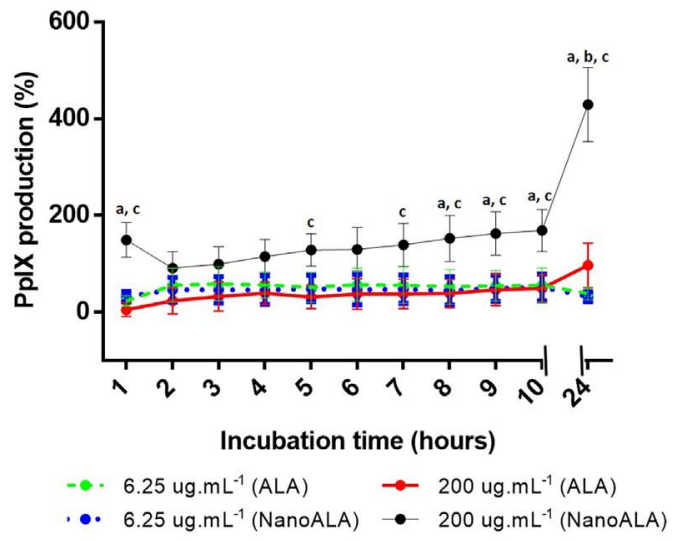

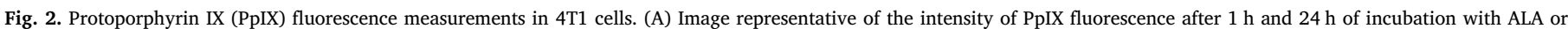

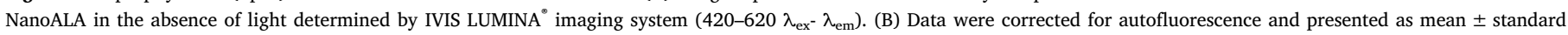

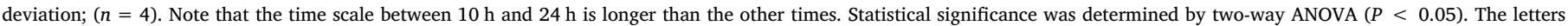

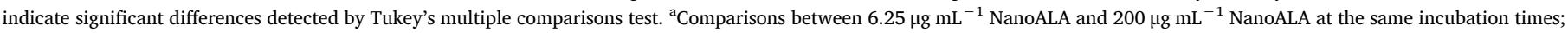
${ }^{\mathrm{b}}$ Comparisons between different incubation times with $200 \mu \mathrm{g} \mathrm{mL} \mathrm{mL}^{-1}$ NanoALA; ${ }^{\mathrm{C}}$ Comparisons between $200 \mu \mathrm{gL} \mathrm{m}^{-1} \mathrm{NanoALA}$ and $200 \mu \mathrm{g} \mathrm{mL}{ }^{-1} \mathrm{ALA}$ at the same incubation times. 


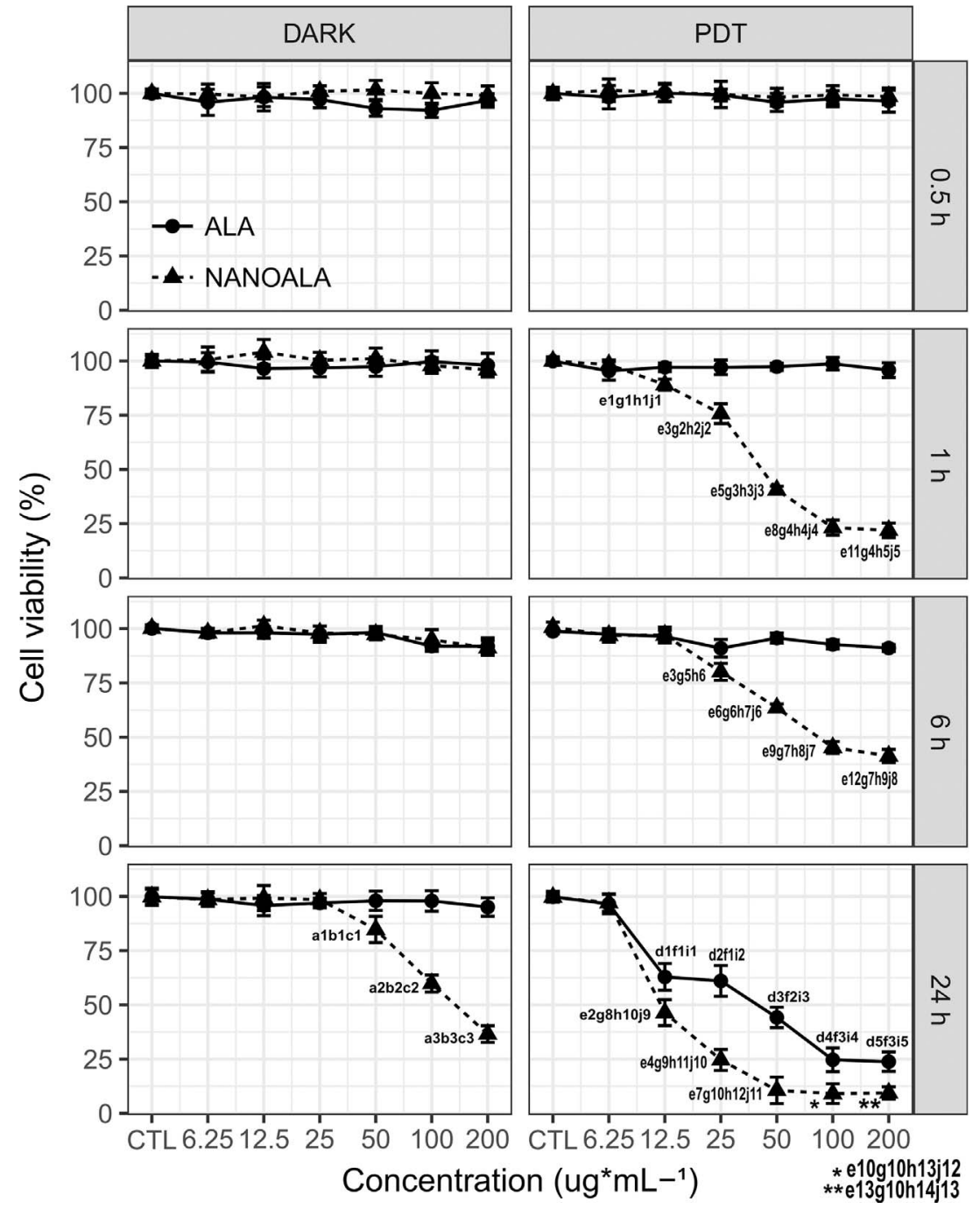

Fig. 3. NanoALA- and ALA-mediated photodynamic therapy effect on viability of the $4 \mathrm{~T} 1$ cells determined by MTT ((4,5-dimethylthiazol-2yl)-2,5-diphenyltetrazolium bromide) assay. Cells were incubated with NanoALA ( $\mathbf{A}$ ) or ALA ( $)$ at concentrations ranging from 6.25 to $200 \mathrm{ug} \mathrm{mL}{ }^{-1}$ for different periods of time $(0.5 \mathrm{~h}$ to $24 \mathrm{~h})$ in the presence and absence of light. Data were presented as mean \pm standard deviation from three independent experiments. Statistical significance was determined by two-way ANOVA $(P<0.05)$. The letters indicate the types of comparisons made and the numbers indicate the significant differences between the comparisons detected by Tukey's multiple comparisons test. ${ }^{\text {a }}$ Comparisons between different incubation times with the same concentrations of NanoALA in the dark; ${ }^{\mathrm{b}}$ Comparisons between different concentrations of NanoALA at the same incubation time in the dark; ${ }^{\mathrm{c} C o m p a r i s o n s ~ b e t w e e n ~ A L A ~ a n d ~}$ NanoALA at the same concentrations and at the same incubation time in the dark; ${ }^{\mathrm{d}}$ Comparisons between different incubation times with the same concentrations of ALA-PDT; ${ }^{\mathrm{e}}$ Comparisons between different incubation times with the same concentrations of NanoALA-PDT; ${ }^{\mathrm{f}}$ Comparisons between different concentrations of ALA-PDT at the same incubation time; ${ }^{8}$ Comparisons between different concentrations of NanoALA-PDT at the same incubation time; ${ }^{\mathrm{h}}$ Comparisons between ALA-PDT and NanoALA-PDT at the same concentrations and at the same incubation time; ${ }^{\mathrm{i}}$ Comparisons between ALA in the dark and ALA-PDT at the same concentrations and at the same incubation time; ${ }^{\mathrm{j}}$ Comparisons between NanoALA in the dark and NanoALA-PDT at the same concentrations and at the same incubation time.

\subsection{Analysis of mitochondrial membrane potential $\left(\Delta \psi_{m}\right)$}

Consistent with mitochondrial leakage, the results indicated that the $\Delta \psi_{\mathrm{m}}$ of $4 \mathrm{~T} 1$ cells was significantly reduced from $97 \%$ to $78 \%$ by NanoALA-PDT treatment, compared with irradiated control. Treatment with NanoALA or ALA in the dark and ALA-PDT did not induce changes in $\Delta \psi_{\mathrm{m}}$ (Fig. 6).

\subsection{Reactive oxygen species (ROS) measurement}

Fig. 7 represents the amount of ROS produced per living cell. The remaining cells of the NanoALA-PDT group had about two times more
ROS compared to the other groups evaluated, indicating that the NanoALA sample led to a much greater increase in the ROS level than free ALA after irradiation. It is important to note that in the dark, NanoALA does not increase the production of cytotoxic ROS.

\subsection{DNA fragmentation}

To further characterize the growth inhibitory effects observed by MTT assay, DNA fragmentation analyses were performed. As shown in Fig. 8, NanoALA-PDT resulted in an increase in DNA fragmentation by approximately 12 -fold compared to the control, probably causing a blockage in the G1 phase of the cell cycle.
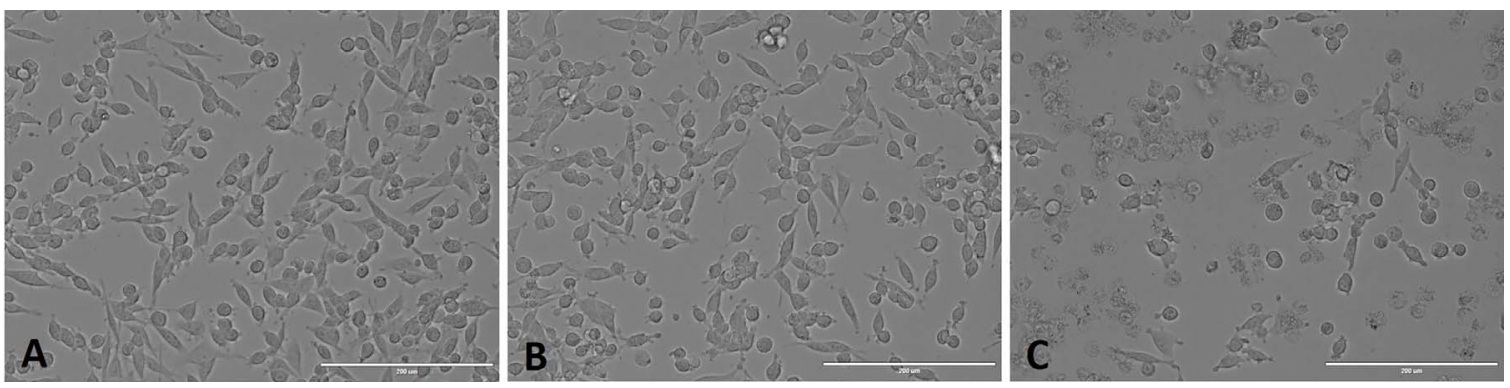

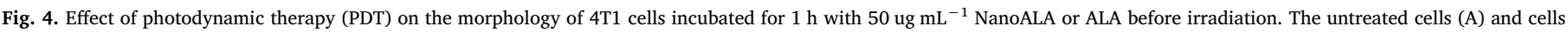
treated with ALA-PDT (B) displayed a standard shape with no cell death. Cells treated with NanoALA-PDT (C) present evident morphological abnormalities. Scale: $200 \mu \mathrm{m}$. 
A

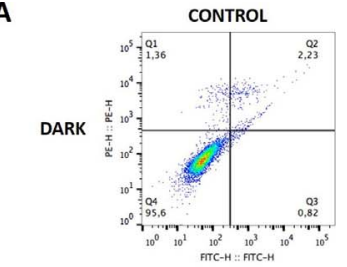
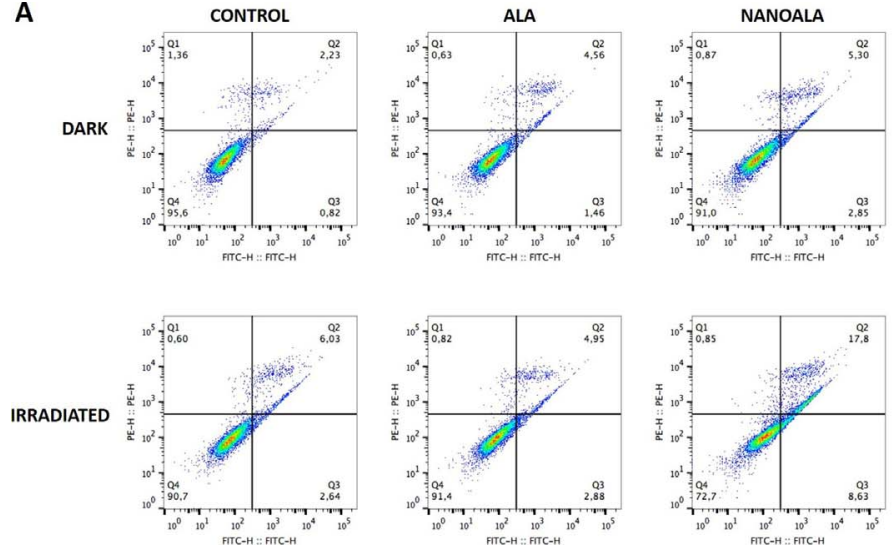

B

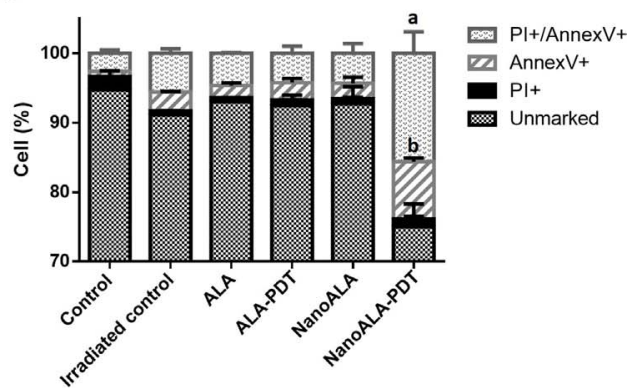

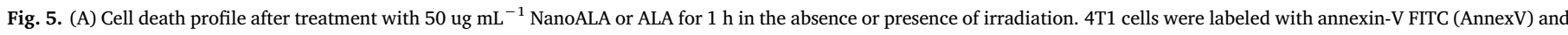

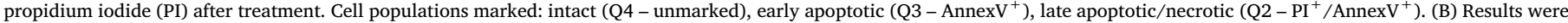

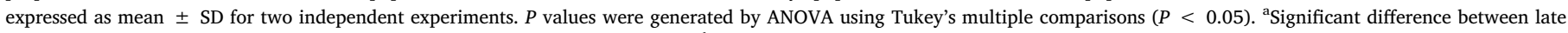

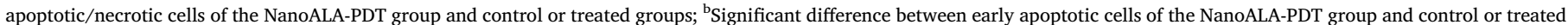
groups.

A

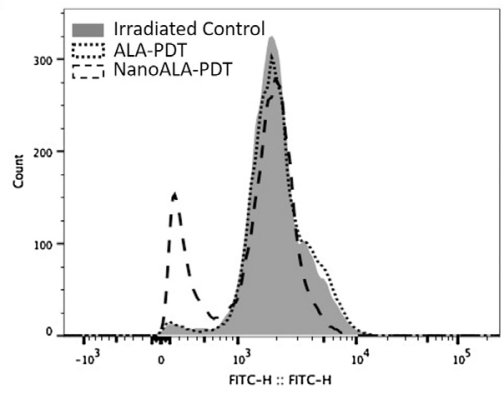

B

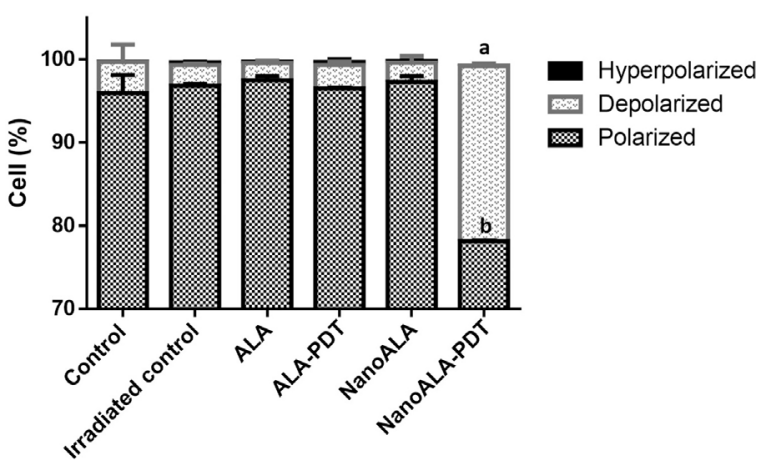

Fig. 6. Analysis of the mitochondrial membrane potential $\left(\Delta \psi_{\mathrm{m}}\right)$ by flow cytometry. (A) Representative fluorescence histogram of the $\Delta \psi_{\mathrm{m}}$ of cells treated with $50 \mathrm{ug} \mathrm{mL}^{-1}$ NanoALA or ALA for $1 \mathrm{~h}$ in the presence of irradiation and stained with Rhodamine 123 . Loss of the Rhodamine 123 dye accumulation indicates dissipation of $\Delta \psi_{\mathrm{m}}$. (B) Bar graphs represent $\%$ of polarized (normal $\Delta \psi_{\mathrm{m}}$ ), depolarized (dissipation of $\Delta \psi_{\mathrm{m}}$ ) and hyperpolarized cells (enhanced $\Delta \psi_{\mathrm{m}}$ ). Values are mean \pm SD for two independent experiments. Statistical significance was determined by ANOVA and Tukey's test for multiple comparisons $(P<0.05)$. 'Significant differences between depolarized cells of the NanoALAPDT group and control or treated groups; 'bignificant differences between polarized cells of the NanoALA-PDT group and control or treated groups.

\section{Discussion}

This work aimed to evaluate the biocompatibility of PLGA-nanocapsules loaded with ALA (NanoALA) and their efficacy/efficiency in mediating PDT in a highly carcinogenic and invasive in vitro model. The results demonstrate that the highly stable-as-produced nanocarrier promotes greater uptake of the prodrug by $4 \mathrm{~T} 1$ cells. As a result, in a short incubation time - equivalent to $1 \mathrm{~h}$ - up to $70 \%$ more cells were killed than following the use of ALA-PDT. It is notable that in this
A

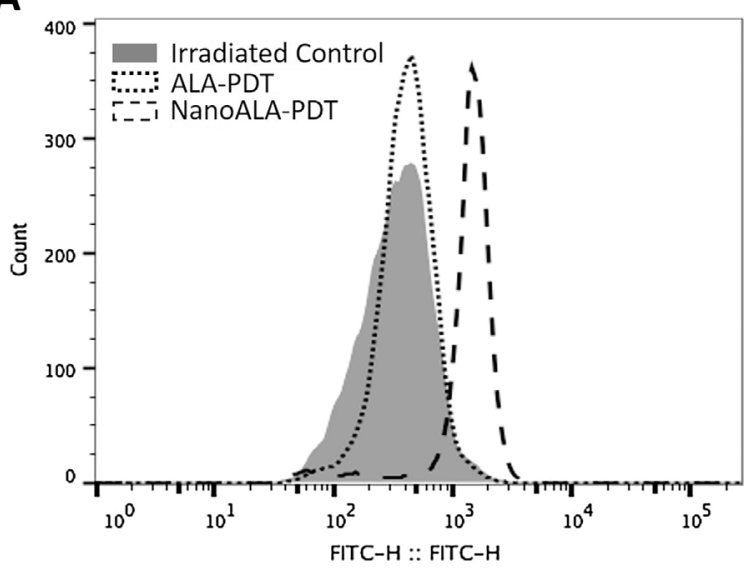

B

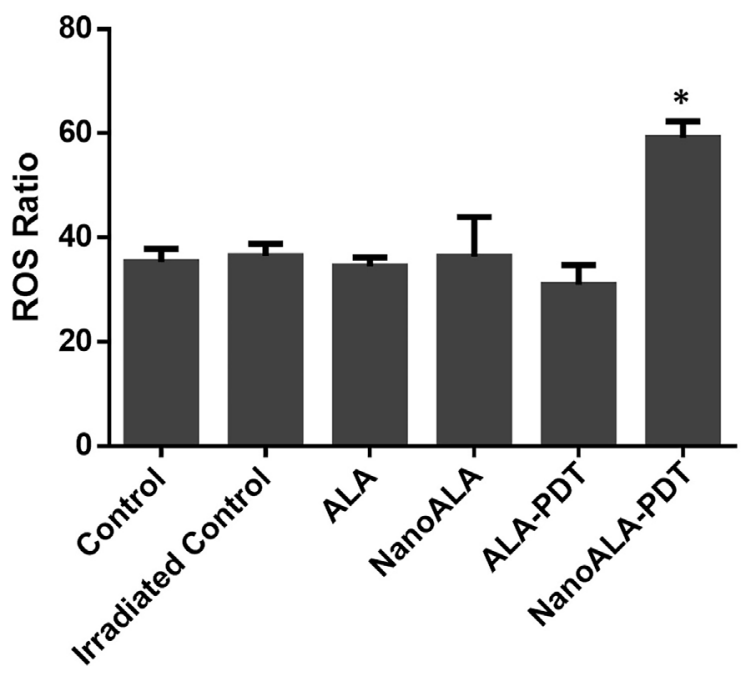

Fig. 7. Detection of intracellular reactive oxygen species (ROS) in $4 \mathrm{~T} 1$ cells by flow cytometry. (A) Representative fluorescence histogram of the ROS levels detected by CellROX Green ${ }^{\circ}$ reagent after exposure to $50 \mathrm{ug} \mathrm{mL}^{-1}$ NanoALA or ALA for $1 \mathrm{~h}$ in the presence of irradiation. (B) Bar graphs represent the ROS ratio (ROS production/live cells). Values are mean \pm SD for two independent experiments. Statistical significance was determined by ANOVA and Tukey's test for multiple comparisons $(P<0.05)$. Asterisks indicate significant differences compared to control and treated groups. 
A

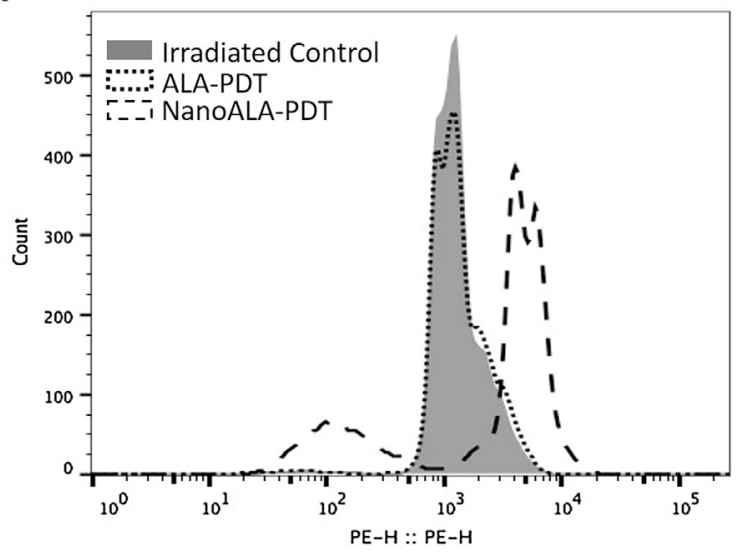

B

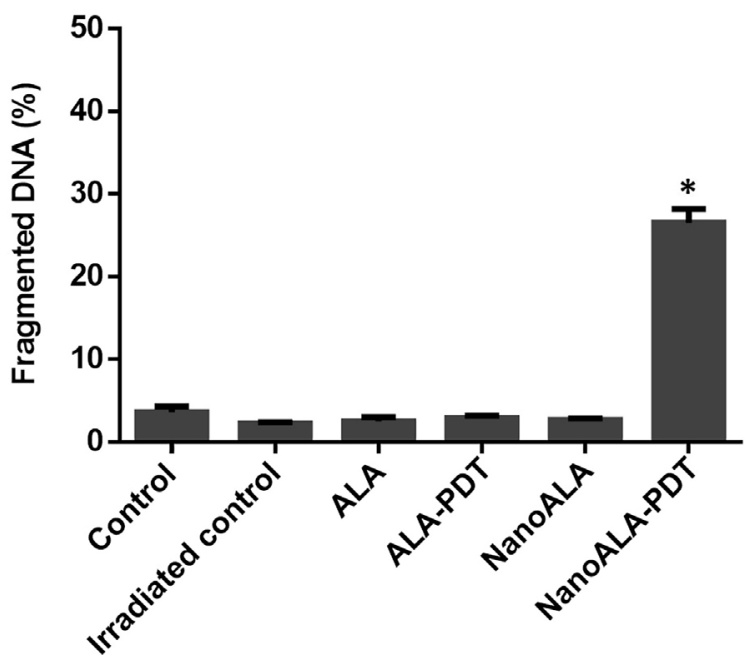

Fig. 8. (A) Analysis of DNA integrity after treatments with $50 \mathrm{ug} \mathrm{mL}{ }^{-1}$ NanoALA or ALA for $1 \mathrm{~h}$ in the presence of irradiation. (B) Bar graphs represent $\%$ of fragmented DNA. Values are mean \pm SD for two independent experiments. Statistical significance was determined by ANOVA and Tukey's test for multiple comparisons $(P<0.05)$. Asterisks indicate significant differences compared to control and treated groups.

period, NanoALA is biocompatible even at the highest concentrations tested. As expected, after irradiation the NanoALA sample led to a much greater increase in the level of reactive oxygen species than ALA, an important indicator of PDT efficiency.

Under physiological conditions ALA undergoes dimerization. The unprotonated amino group reacts with the ketone group from the neighboring molecule to form products such as 3,6-dihydropyrazine2,5-dipropanoic acid (DHPY) and 2,5-( $\beta$-carboxyethyl)pyrazine (PY), resulting in a loss of biological activity $[5,47,48]$. So, it is possible that a free ALA fraction has been degraded in the culture medium, which would, at least in part, explain the restricted ALA transport rate to the intracellular environment and the insufficient PpIX production to overload the heme biosynthesis pathway and generate cytotoxicity at shorter exposure times. In contrast, the anchoring of the prodrug molecules in the interfacial domain of the PLGA nanocapsules can increase their stability [2] and favor a higher uptake via endocytosis, compared to the conventional uptake of free ALA via active transport $[11,38]$.

Although the nanovehicle favored the incorporation of prodrug into the cells, the photocytotoxic effect of NanoALA did not progress continuously, and milder effects were observed at $6 \mathrm{~h}$ of incubation in comparison to $1 \mathrm{~h}$. The existence of transporters that cause PpIX efflux, such as ABCG2, an ATP-binding cassette transporter, as well as the conversion of PpIX to heme in the presence of iron by the enzyme ferrochelatase, discourage the accumulation of FS and, therefore, reduce the PDT efficacy [43]. The PpIX was probably partially metabolized or exported during the first hours of incubation, causing a slight reduction in fluorescence between $1 \mathrm{~h}$ and $6 \mathrm{~h}$. Albeit not significant, this may have been enough to generate different cytotoxic effects.

The mechanism underlying the anti-tumorigenic effect of PDT is modulated by multiple factors, but low doses of PDT and photosensitizer located in mitochondria usually direct cells towards apoptosis, whereas high doses of PDT and photosensitizer localized in plasma membrane and lysosomes cause necrosis [10]. Our results confirm that PpIX-loaded mitochondria are the initial targets of NanoALA-photoinduced damage. Most likely, mitochondrial leakage caused by oxidative stress resulted in dissipation of the $\Delta \psi_{\mathrm{m}}$ and alterations in energy metabolism, particularly in the failure of oxidative phosphorylation and progressive depletion of adenosine tryphosphate (ATP), triggering cell death via apoptosis. An increase in DNA fragmentation is a common feature of apoptotic cells, which reinforces our conjecture.

We searched the scientific literature for the effectiveness of ALAmediated PDT conjugated to nanoparticles (assessed by MTT cell viability assay) (see Table 2). In most of the papers presented, the irradiation is often carried out following 4-6 h of incubation with nanostructured ALA. This is the first work to show a reduction in cell viability of approximately $80 \%$ in just one hour of incubation, with a relatively low concentration of NanoALA ( $100 \mu \mathrm{g} \mathrm{mL}{ }^{-1}-0.6 \mathrm{mM}$ ALA equivalent). More interestingly, the use of NanoALA reduced by 4 times the required ALA concentration for inducing the same therapeutic effect. These results are very convenient for clinical practice, because NanoALAmediated PDT will avoid the probable adverse effects on healthy tissues, in addition to reducing the operational cost for the health system.

\section{Conclusion}

Aminolevulic acid-loaded PLGA nanocapsules, denominated NanoALA, emerge as a promising strategy for anti-cancer PDT. It was evidenced that the nanostructured end product enhances the stability of the prodrug under physiological conditions and promotes greater uptake by $4 \mathrm{~T} 1$ tumor cells. These results are convenient for clinical practice, in terms of efficacy and efficiency, where shorter exposure times and lower concentration are desired to achieve the expected therapeutic effect with minimal adverse effects. Now other biological parameters such as biodistribution, biocompatibility and in vivo efficacy should be investigated to complement this study and to ensure the safe and broad clinical use of NanoALA-mediated PDT.

\section{Conflict of interests}

Authors declare no conflict of interests.

\section{Acknowledgments}

We acknowledge Professor Dr. Paulo E N de Souza and the students Rodrigo Barbosa Nunes and Pedro Alencar G Pereira of the Laboratory of Software and Instrumentation in Applied Physics, Institute of Physics, University of Brasilia, for developing and building the LED equipment used in this work. We also acknowledge the Coordination for Further Training of Graduate Staff (CAPES), the Brazilian National Council for Technological and Scientific Development (CNPq), the Foundation to Support Research in the Federal District (FAPDF), Network of Nanobiotechnology CON-NANO (CAPES), National Institute of Science and Technology in Nanobiotechnology (INCTNanobiotecnologia), Center for Nanoscience and Nanobiotechnology of the University of Brasília (CNANO-UnB), and the Dean of Research and Post-Graduation of the University of Brasília (DPP-UnB) for financial support. 
Table 2

Effectiveness of ALA-mediated PDT conjugated to nanoparticles assessed by MTT cell viability assay: a review.

\begin{tabular}{|c|c|c|c|c|c|c|}
\hline Author & ALA nanocarriers & Concentration & Exposure time & Irradiation conditions & Cell line & $\begin{array}{l}\% \text { Cell viability (best } \\
\text { condition) }\end{array}$ \\
\hline Battah et al. [12] & Dendrimers (D16 and D21) & $\begin{array}{l}0.1 \mathrm{mM} \text { and } \\
0.5 \mathrm{mM}\end{array}$ & $4 \mathrm{~h}$ & $\begin{array}{l}\text { Power density: } 40 \mathrm{~mW} / \mathrm{cm}^{2} \\
\text { Energy density: } 5 \mathrm{~J} / \mathrm{cm}^{2}\end{array}$ & PAM 212 & $20 \%(\mathrm{D} 21-0.5 \mathrm{mM})$ \\
\hline Oo et al. [26] & Gold nanoparticles & $1 \mathrm{mM}$ & $4 \mathrm{~h}$ & $\begin{array}{l}\text { Light Source: } 150 \mathrm{w} \text { halogen } \\
\text { lamp for } 1 \mathrm{~min}\end{array}$ & $\begin{array}{l}\text { NHDF } \\
\text { HT } 1080\end{array}$ & $30 \%$ \\
\hline Huang et al. [30] & $\begin{array}{l}\text { Dendrimer-modified multi-walled carbon } \\
\text { nanotubes }\end{array}$ & $0-100 \mu \mathrm{M}$ & $24 \mathrm{~h}$ & Energy density: $4.35 \mathrm{~J} / \mathrm{cm}^{2}$ & MGC-803 & $10 \%(>30 \mu \mathrm{M})$ \\
\hline Xu et al. [33] & Cationic gold nanoparticles & 1,2 and $3 \mathrm{mM}$ & $4 h$ & $\begin{array}{l}\text { Power density: } 1 \mathrm{~mW} / \mathrm{cm}^{2} \\
\text { Time: } 1 \mathrm{~h} \\
\text { Light sources: } \\
\text { - Mercury lamp } \\
\text { - Purple LEDs } \\
\text { - Green LEDs } \\
\text { - Red LEDs }\end{array}$ & K562 & $\begin{array}{l}30 \% \text { (Green LEDs }-2 \\
\text { and } 3 \mathrm{mM} \text { ) }\end{array}$ \\
\hline Benito et al. [14] & $\begin{array}{l}\text { Gold nanoparticles: } \\
\text { - ALA-AuNP1 (14-nm-diameter) } \\
\text { - ALA-AuNP2 - (136 nm of diameter) }\end{array}$ & $200 \mu \mathrm{M}$ & $4 \mathrm{~h}$ & $\begin{array}{l}\text { Power density: } 40 \mathrm{~mW} / \mathrm{cm}^{2} \\
\text { Time: } 7 \mathrm{~min} \\
\lambda: 640 \mathrm{~nm} \text {, Distance: } 8 \mathrm{~cm} \text { from } \\
\text { the cells }\end{array}$ & HeLa & 19.1\% (ALA-AuNP2) \\
\hline $\begin{array}{l}\text { Mohammadi et al. } \\
\text { [34] }\end{array}$ & Gold nanoparticles & $1 \mathrm{mM}$ & $4 \mathrm{H}$ & $\begin{array}{l}\text { Light Source: He-Ne laser } \\
\text { Energy density: } 20,40,60 \text { and } \\
80 \mathrm{~J} / \mathrm{cm}^{2}\end{array}$ & MeL-Rm & $\sim 30 \%\left(60 \mathrm{~J} / \mathrm{cm}^{2}\right)$ \\
\hline Chung et al. [21] & $\begin{array}{l}\text { Methoxy polyethylene glycol/chitosan } \\
\text { (PEG-Chito) copolymer }\end{array}$ & $0.1 \mathrm{mM}$ & $24 \mathrm{~h}$ & $\begin{array}{l}\text { Light Source: } 635 \mathrm{~nm} \text { LED } \\
\text { Energy density: } 0.6,1.2 \text {, and } \\
1.8 \mathrm{~J} / \mathrm{cm}^{2}\end{array}$ & CT26 & $30 \%\left(1.8 \mathrm{~J} / \mathrm{cm}^{2}\right)$ \\
\hline Rodriguez et al. [13] & $\begin{array}{l}\text { Dendrimers carrying } 6 \text { and } 9 \text { ALA } \\
\text { residues ( } 6 \mathrm{~m}-\mathrm{ALA} \text { and 9m-ALA) }\end{array}$ & $0.025 \mathrm{mM}$ & $3 \mathrm{~h}$ & $\begin{array}{l}\text { Energy density: } 0.15 \mathrm{~J} / \mathrm{cm}^{2}- \\
\text { LM3 cell } \\
\text { Energy density: } 0.6 \mathrm{~J} / \mathrm{cm}^{2}- \\
\text { HMEC-1 and Raw } 264.7\end{array}$ & $\begin{array}{l}\text { LM3 } \\
\text { HMEC-1 } \\
\text { Raw264.7 }\end{array}$ & $\begin{array}{l}0 \% \text { (LM3 cell }-9 \mathrm{~m}- \\
\text { ALA) } \\
0 \% \text { (Raw264.7) }\end{array}$ \\
\hline Zhang et al. [36] & 5-ALA-GNPs & $2 \mathrm{mM}$ & $6 \mathrm{~h}$ & $\begin{array}{l}\text { Energy density: } 24 \mathrm{~J} / \mathrm{cm}^{2} \\
\text { Light Source: } \\
\text { - 502-nm LED } \\
\text { - 635-nm Laser } \\
\text { - Xenon lamp }\end{array}$ & K562 & $\sim 30 \%$ (LED) \\
\hline Feng et al. [37] & $\begin{array}{l}\text { CIS/ZnS QDs-ALA (Quantum dots-ALA } \\
\text { conjugates) }\end{array}$ & $1 \mathrm{mM}$ and $2 \mathrm{mM}$ & $4 \mathrm{~h}$ & $\begin{array}{l}\text { Light Source: Femtosecond laser } \\
\text { with pulse widths of } 50 \mathrm{fs} \\
\text { Power: } 100 \mathrm{Mw} \\
\text { Time: } 120 \mathrm{~s}\end{array}$ & MCF-7 & $(<40 \%)(2 \mathrm{mM})$ \\
\hline Wu et al. [7] & $\begin{array}{l}\text { Thiolated stealth peptide and hydrazone- } \\
\text { containing ALA to gold nanoparticles }\end{array}$ & $50 \mu \mathrm{g} / \mathrm{mL}$ & $4 \mathrm{~h}$ & $\begin{array}{l}\text { Light Source: } 635 \mathrm{~nm} \text { laser } \\
\text { Power: } 500 \mathrm{~mW} \\
\text { Times: } 0.5 \mathrm{~min} \text { to } 10 \mathrm{~min} .\end{array}$ & A549 & $\begin{array}{l}25 \%(5 \mathrm{~min} \text { light } \\
\text { irradiation) }\end{array}$ \\
\hline Shi et al. [38] & $\begin{array}{l}\text { ALA loaded poly(lactic-co-glycolic acid) } \\
\text { nanoparticles }\end{array}$ & $0.1 \mathrm{mM}$ & $6 \mathrm{~h}$ and $24 \mathrm{~h}$ & $\begin{array}{l}\text { Light Source: } 632.8 \mathrm{~nm} \text { helium- } \\
\text { neon laser } \\
\text { Power density: } 8.6 \mathrm{~mW} / \mathrm{cm}^{2} \\
\text { Energy density: } 8 \mathrm{~J} / \mathrm{cm}^{2}\end{array}$ & A431 & $20 \%(24 \mathrm{~h})$ \\
\hline
\end{tabular}

\section{References}

[1] S.R. Millon, J.H. Ostrander, S. Yazdanfar, J.Q. Brown, J.E. Bender, A. Rajeha, N. Ramanujam, Preferential accumulation of 5-aminolevulinic acid-induced protoporphyrin IX in breast cancer: a comprehensive study on six breast cell lines with varying phenotypes, J. Biomed. Opt. 15 (2010) 18002-18008, http://dx.doi.org/ 10.1117/1.3302811.

[2] S.K. Passos, P.E. de Souza, P.K. Soares, D.R. Eid, F.L. Primo, A. Cláudio Tedesco, Z.G. Lacava, P.C. Morais, Quantitative approach to skin field cancerization using a nanoencapsulated photodynamic therapy agent: a pilot study, Clin. Cosmet. Investig. Dermatol. 6 (2013) 51-59, http://dx.doi.org/10.2147/CCID.S36758.

[3] S.-J. Yang, F.-H. Lin, H.-M. Tsai, C.-F. Lin, H.-C. Chin, J.-M. Wong, M.-J. Shieh, Alginate-folic acid-modified chitosan nanoparticles for photodynamic detection of intestinal neoplasms, Biomaterials 32 (2011) 2174-2182, http://dx.doi.org/10. 1016/j.biomaterials.2010.11.039.

[4] X. Yang, P. Palasuberniam, D. Kraus, B. Chen, Aminolevulinic acid-Based tumor detection and therapy: molecular mechanisms and strategies for enhancement, Int J. Mol. Sci. 16 (2015) 25865-25880, http://dx.doi.org/10.3390/ijms161025865.

[5] I. Miletto, E. Bottinelli, A. Siviero, D. Fabbri, P. Calza, G. Berlier, Mesoporous nanocarriers for the loading and stabilization of 5-aminolevulinic acid, J. Nanoparticle Res. 18 (2016) 227, http://dx.doi.org/10.1007/s11051-016-3535-6.

[6] C. Thunshelle, R. Yin, Q. Chen, M.R. Hamblin, Current advances in 5-aminolevulinic acid mediated photodynamic therapy, Curr. Dermatol. Rep. 5 (2016) 179-190, http://dx.doi.org/10.1007/s13671-016-0154-5.

[7] J. Wu, Y. Lin, H. Li, Q. Jin, J. Ji, Zwitterionic stealth peptide-capped 5-aminolevulinic acid prodrug nanoparticles for targeted photodynamic therapy, J. Colloid Interface Sci. 485 (2017) 251-259, http://dx.doi.org/10.1016/j.jcis.2016.09.012.

[8] S.M. Banerjee, A.J. MacRobert, C.A. Mosse, B. Periera, S.G. Bown, M.R.S. Keshtgar, Photodynamic therapy: inception to application in breast cancer, Breast 31 (2017) 105-113, http://dx.doi.org/10.1016/j.breast.2016.09.016.

[9] U. Chitgupi, Y. Qin, J.F. Lovell, Targeted nanomaterials for phototherapy, Nanotheranostics 1 (2017) 38-58, http://dx doi.org/10.7150/ntno.17694.

[10] U. Chilakamarthi, L. Giribabu, Photodynamic therapy: past, present and future, 
Chem. Rec. (2017), http://dx.doi.org/10.1002/tcr.201600121.

[11] E.J. Hong, D.G. Choi, M.S. Shim, Targeted and effective photodynamic therapy for cancer using functionalized nanomaterials, Acta Pharm. Sin. B 6 (2016) 297-307, http://dx.doi.org/10.1016/j.apsb.2016.01.007.

[12] S.H. Battah, C.-E. Chee, H. Nakanishi, S. Gerscher, A.J. MacRobert, C. Edwards, Synthesis and biological studies of 5-aminolevulinic acid-Containing dendrimers for photodynamic therapy, Bioconjug. Chem. 12 (2001) 980-988, http://dx.doi.org/ 10.1021/bc010027n.

[13] L. Rodriguez, P. Vallecorsa, S. Battah, G. Di Venosa, G. Calvo, L. Mamone, D. Saenz, M.C. Gonzalez, A. Batlle, A.J. MacRobert, A. Casas, Aminolevulinic acid dendrimers in photodynamic treatment of cancer and atheromatous disease, Photochem. Photobiol. Sci. 14 (2015) 1617-1627, http://dx.doi.org/10.1039/C5PP00126A.

[14] M. Benito, V. Martin, M.D. Blanco, J.M. Teijon, C. Gomez, Cooperative effect of 5aminolevulinic acid and gold nanoparticles for photodynamic therapy of cancer, J. Pharm. Sci. 102 (2013) 2760-2769, http://dx.doi.org/10.1002/jps.23621.

[15] E. Rud, O. Gederaas, A. Høgset, K. Berg, 5-Aminolevulinic acid, but not 5-aminolevulinic acid esters, is transported into adenocarcinoma cells by system BETA transporters, Photochem. Photobiol. 71 (2000) 640, http://dx.doi.org/10.1562/ 0031-8655(2000)071 < 0640:AABNAA > 2.0.CO;2.

[16] C. Gómez, M. Benito, I. Katime, J.M. Teijón, M.D. Blanco, In vitro transdermal and biological evaluation of ALA-loaded poly( $\mathrm{N}$-isopropylacrylamide) and poly $(\mathrm{N}$-isopropylacrylamide-co-acrylic acid) microgels for photodynamic therapy, $\mathrm{J}$. Microencapsul. 29 (2012) 626-635, http://dx.doi.org/10.3109/02652048.2012. 676091.

[17] J. Yang, Y. Xia, X. Liu, S. Jiang, L. Xiong, Desferrioxamine shows different potentials for enhancing 5-aminolaevulinic acid-based photodynamic therapy in several cutaneous cell lines, Lasers Med. Sci. 25 (2010) 251-257, http://dx.doi.org/10.1007/ s10103-009-0721-0.

[18] F.S. De Rosa, J.M. Marchetti, J.A. Thomazini, A.C. Tedesco, M.V.L.B. Bentley, A vehicle for photodynamic therapy of skin cancer: influence of dimethylsulphoxide on 5-aminolevulinic acid in vitro cutaneous permeation and in vivo protoporphyrin IX accumulation determined by confocal microscopy, J. Control. Release 65 (2000) 359-366, http://dx.doi.org/10.1016/S0168-3659(99)00213-8.

[19] R.F.V. Lopez, M.V.L.B. Bentley, M.B. Delgado-Charro, R.H. Guy, Iontophoretic delivery of 5-aminolevulinic acid (ALA): effect of pH, Pharm. Res. 18 (2001) 311-315, http://dx.doi.org/10.1023/A:1011050829531.

[20] F.S. De Rosa, A.C. Tedesco, R.F.V. Lopez, M.B. Riemma Pierre, N. Lange, J.M. Marchetti, J.C. Gomes Rotta, M.V. Lopes Badra Bentley, In vitro skin permeation and retention of 5-aminolevulinic acid ester derivatives for photodynamic therapy, J. Control. Release 89 (2003) 261-269, http://dx.doi.org/10.1016/S01683659(03)00125-1.

[21] C.W. Chung, K.D. Chung, Y. Il Jeong, D.H. Kang, 5-aminolevulinic acid-incorporated nanoparticles of methoxy poly(ethylene glycol)-chitosan copolymer for photodynamic therapy, Int. J. Nanomed. 8 (2013) 809-819, http://dx.doi.org/10. 2147/IJN.S39615.

[22] R.A. Jain, The manufacturing techniques of various drug loaded biodegradable poly (lactide-co-glycolide) (PLGA) devices, Biomaterials 21 (2000) 2475-2490, http:// dx.doi.org/10.1016/S0142-9612(00)00115-0.

[23] J.-M. Lü, X. Wang, C. Marin-Muller, H. Wang, P.H. Lin, Q. Yao, C. Chen, Current advances in research and clinical applications of PLGA-based nanotechnology, Expert Rev. Mol. Diagn. 9 (2009) 325-341, http://dx.doi.org/10.1586/erm.09.15.

[24] H.K. Makadia, S.J. Siegel, Poly lactic-co-glycolic acid (PLGA) as biodegradable controlled drug delivery carrier, Polymers (Basel) 3 (2011) 1377-1397, http://dx. doi.org/10.3390/polym3031377.

[25] M.B.R. Pierre, A.C. Tedesco, J.M. Marchetti, M.V.L.B. Bentley, Stratum corneum lipids liposomes for the topical delivery of 5-aminolevulinic acid in photodynamic therapy of skin cancer: preparation and in vitro permeation study, BMC Dermatol. 1 (2001) 5, http://dx.doi.org/10.1186/1471-5945-1-5.

[26] M.K. Khaing Oo, X. Yang, H. Du, H. Wang, 5-aminolevulinic acid-conjugated gold nanoparticles for photodynamic therapy of cancer, Nanomedicine 3 (2008) 777-786, http://dx.doi.org/10.2217/17435889.3.6.777.

[27] T. Maisch, F. Santarelli, S. Schreml, P. Babilas, R.-M. Szeimies, Fluorescence induction of protoporphyrin IX by a new 5 -aminolevulinic acid nanoemulsion used for photodynamic therapy in a full-thickness ex vivo skin model, Exp. Dermatol. 19 (2009) e302-e305, http://dx.doi.org/10.1111/j.1600-0625.2009.01001.x.

[28] S.-J. Yang, M.-J. Shieh, F.-H. Lin, P.-J. Lou, C.-L. Peng, M.-F. Wei, C.-J. Yao, P.S. Lai, T.-H. Young, Colorectal cancer cell detection by 5 -aminolaevulinic acidloaded chitosan nano-particles, Cancer Lett. 273 (2009) 210-220, http://dx.doi. org/10.1016/j.canlet.2008.08.014.

[29] S.-J. Yang, F.-H. Lin, K.-C. Tsai, M.-F. Wei, H.-M. Tsai, J.-M. Wong, M.-J. Shieh, Folic acid-conjugated chitosan nanoparticles enhanced protoporphyrin IX accumulation in colorectal cancer cells, Bioconjug. Chem. 21 (2010) 679-689, http://dx.doi.org/10.1021/bc9004798.

[30] P. Huang, J. Lin, D. Yang, C. Zhang, Z. Li, D. Cui, Photosensitizer-loaded dendrimermodified multi-walled carbon nanotubes for photodynamic therapy, J. Control. Release 152 (2011) e33-e34, http://dx.doi.org/10.1016/j.jconrel.2011.08.105.

[31] E. Kyung Oh, S.-E. Jin, J.-K. Kim, J.-S. Park, Y. Park, C.-K. Kim, Retained topical delivery of 5-aminolevulinic acid using cationic ultradeformable liposomes for photodynamic therapy, Eur. J. Pharm. Sci. 44 (2011) 149-157, http://dx.doi.org/ 10.1016/j.ejps.2011.07.003.

[32] L.-W. Zhang, Saleh A. Al-suwayeh, Chi-F. Hung, Chih-chieh Chen, J.-Y. Fang, Oil components modulate the skin delivery of 5-aminolevulinic acid and its ester prodrug from oil-in-water and water-in-oil nanoemulsions, Int. J. Nanomed. 6 (2011) 693-704, http://dx.doi.org/10.2147/IJN.S17524.

[33] H. Xu, C. Liu, J. Mei, C. Yao, S. Wang, J. Wang, Z. Li, Z. Zhang, Effects of light irradiation upon photodynamic therapy based on 5-aminolevulinic acid-gold nanoparticle conjugates in K562 cells via singlet oxygen generation, Int. J. Nanomed. 7 (2012) 5029-5038, http://dx.doi.org/10.2147/IJN.S33261.

[34] Z. Mohammadi, A. Sazgarnia, O. Rajabi, S. Soudmand, H. Esmaily, H.R. Sadeghi, An in vitro study on the photosensitivity of 5-aminolevulinic acid conjugated gold nanoparticles, Photodiagn. Photodyn. Ther. 10 (2013) 382-388, http://dx.doi.org/ 10.1016/j.pdpdt.2013.03.010.

[35] A.J. Plaunt, K.M. Harmatys, K.A. Hendrie, A.J. Musso, B.D. Smith, Chemically triggered release of 5-aminolevulinic acid from liposomes, RSC Adv. 4 (2014) 57983-57990, http://dx.doi.org/10.1039/C4RA10340H.

[36] Z. Zhang, S. Wang, H. Xu, B. Wang, C. Yao, Role of 5-aminolevulinic acid-conjugated gold nanoparticles for photodynamic therapy of cancer, J. Biomed. Opt. 20 (2015) 51043, http://dx.doi.org/10.1117/1.JBO.20.5.051043.

[37] Y. Feng, L. Liu, S. Hu, Y. Liu, Y. Ren, X. Zhang, Forster resonance energy transfer properties of a new type of near-infrared excitation PDT photosensitizer: cuInS2/ ZnS quantum dots-5-aminolevulinic acid conjugates, RSC Adv. 6 (2016) 55568-55576, http://dx.doi.org/10.1039/C6RA06937A.

[38] L. Shi, X. Wang, F. Zhao, H. Luan, Q. Tu, Z. Huang, H. Wang, H. Wang, In vitro evaluation of 5-aminolevulinic acid (ALA) loaded PLGA nanoparticles, Int. J. Nanomed. 8 (2013) 2669-2676, http://dx.doi.org/10.2147/IJN.S45821.

[39] M.N. Theodoraki, K. Lorenz, R. Lotfi, D. Fürst, C. Tsamadou, S. Jaekle, J. Mytilineos, C. Brunner, J. Theodorakis, T.K. Hoffmann, S. Laban, P.J. Schuler, Influence of photodynamic therapy on peripheral immune cell populations and cytokine concentrations in head and neck cancer, Photodiagn. Photodyn. Ther. 19 (2017) 194-201, http://dx.doi.org/10.1016/j.pdpdt.2017.05.015.

[40] J. Xu, L. Xu, C. Wang, R. Yang, Q. Zhuang, X. Han, Z. Dong, W. Zhu, R. Peng, Z. Liu, Near-infrared-triggered photodynamic therapy with multitasking upconversion nanoparticles in combination with checkpoint blockade for immunotherapy of colorectal cancer, ACS Nano 11 (2017) 4463-4474, http://dx.doi.org/10.1021/ colorectal cancer,
acsnano.7b00715.

[41] 4T1 ATCC ${ }^{\circ}$ CRL-2539 ${ }^{\mathrm{Tm}}$ Mus musculus mammary gland This tumor i, (n.d.). https:// www.atcc.org/Products/All/CRL-2539.aspx (Accessed April 29, 2017).

[42] WHO, Breast Cancer Awareness Month in October, WHO, 2012 http://www.who. int/cancer/events/breast_cancer_month/en/ (Accessed April 29, 2017).

[43] T. Ogino, H. Kobuchi, K. Munetomo, H. Fujita, M. Yamamoto, T. Utsumi, K. Inoue, T. Shuin, J. Sasaki, M. Inoue, K. Utsumi, Serum-dependent export of protoporphyrin IX by ATP-binding cassette transporter G2 in T24 cells, Mol. Cell. Biochem. 358 (2011) 297, http://dx.doi.org/10.1007/s11010-011-0980-5.

[44] A.R. Simioni, F.L. Primo, A.C. Tedesco, Silicon(IV) phthalocyanine-loaded-nanoparticles for application in photodynamic process, J. Laser Appl. 24 (2012) 12004, http://dx.doi.org/10.2351/1.3669442.

[45] C.S. De Paula, A.C. Tedesco, F.L. Primo, J.M.C. Vilela, M.S. Andrade, V.C.F. Mosqueira, Chloroaluminium phthalocyanine polymeric nanoparticles as photosensitisers: photophysical and physicochemical characterisation, release and phototoxicity in vitro, Eur. J. Pharm. Sci. 49 (2013) 371-381, http://dx.doi.org/10. 1016/j.ejps.2013.03.011.

[46] P. Mroz, A. Yaroslavsky, G.B. Kharkwal, M.R. Hamblin, Cell death pathways in photodynamic therapy of cancer, Cancers (Basel) 3 (2011) 2516-2539, http://dx. doi.org/10.3390/cancers3022516.

[47] G.A. Hunter, E. Rivera, G.C. Ferreira, Supraphysiological concentrations of 5-aminolevulinic acid dimerize in solution to produce superoxide radical anions via a protonated dihydropyrazine intermediate, Arch. Biochem. Biophys. 437 (2005) 128-137, http://dx.doi.org/10.1016/j.abb.2005.03.007.

[48] A. Babič, V. Herceg, I. Ateb, E. Allémann, N. Lange, Tunable phosphatase-sensitive stable prodrugs of 5-aminolevulinic acid for tumor fluorescence photodetection, J. Control. Release 235 (2016) 155-164, http://dx.doi.org/10.1016/j.jconrel.2016. 05.047 . 